شبيهسازى ضريب دبى سرريزهاى لبه تيز دايرهاى توسط مدل تركيبى انفيس - كرم شبتاب

امير عليزاده، بهروز يعقوبى" و سعيد شعبانلو'

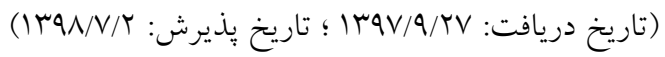

جـكيده

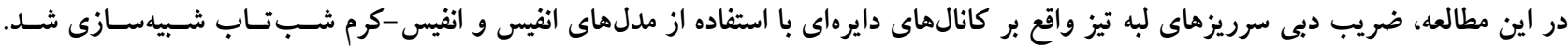

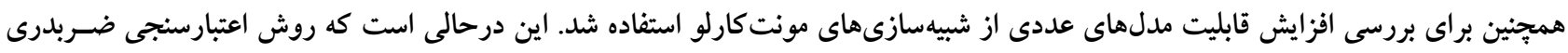

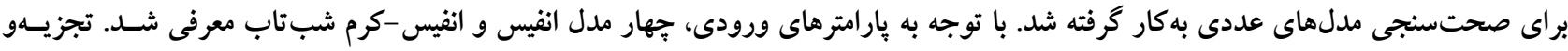

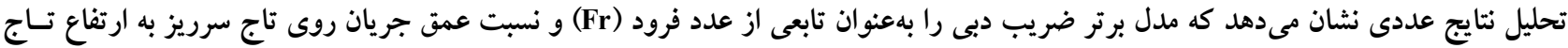

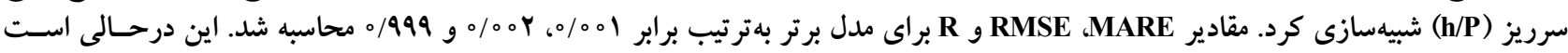
كه حداكثر مقدار MARE براى اين مطالعه كمتر از Y درصد بود.

$$
\text { وازمهاى كليدى: سرريز دايرهاى ، ضريب دبى، شبيسازى، انفيس، الخوريتم كرم شبتاب }
$$


قرار كرفته است. بـهنعـوان مثـال، دورسـان و همكــاران (V) بـانـان

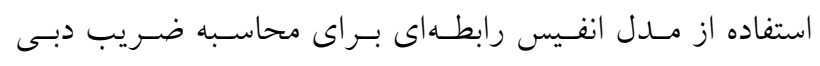

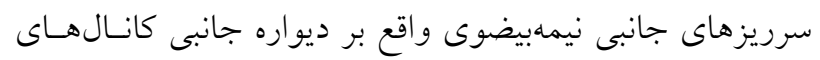

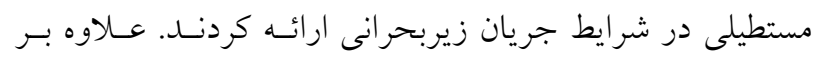

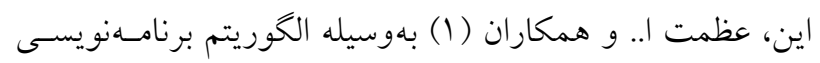

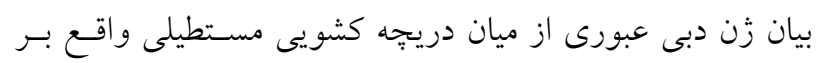

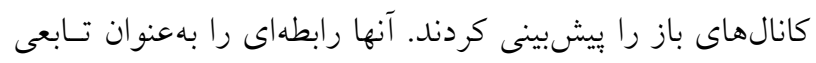

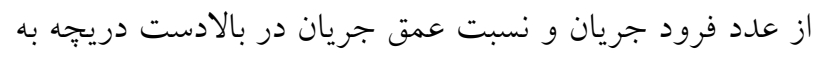

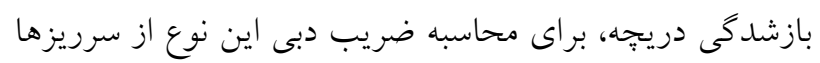

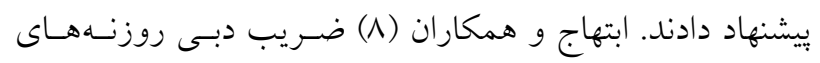

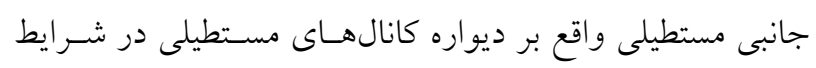

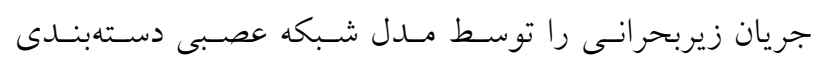

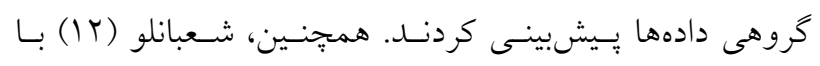

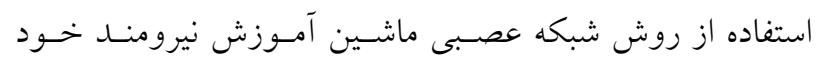
تطبيقى ضريب دبى سرريزهاى دايرهاى شكل را شبيهسازى كرد.

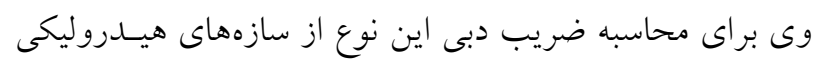
يكى ماتريس بيشنهاد داد. همان كونه كه مشاهده مى شود كانال هاى دايرهاى بـ بـه شـكل

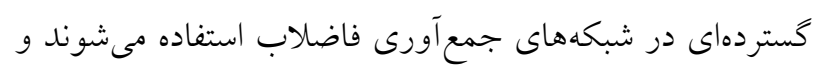

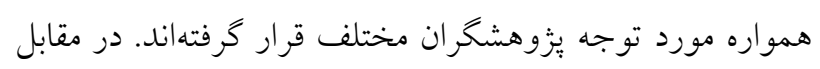

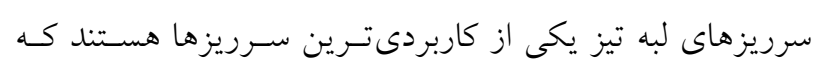

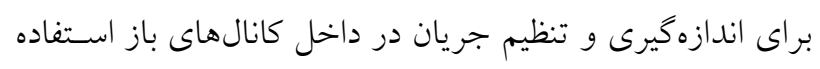

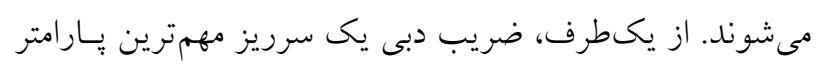

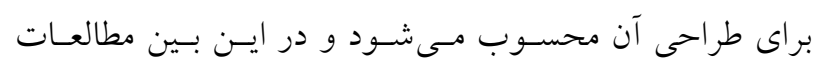

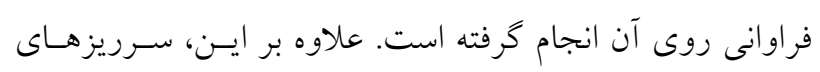

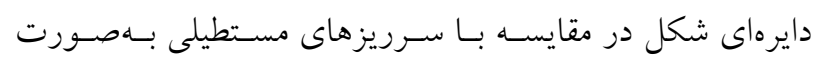

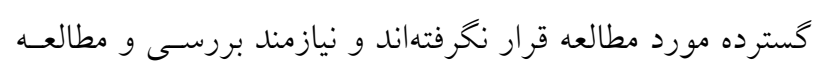

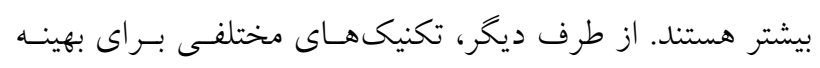

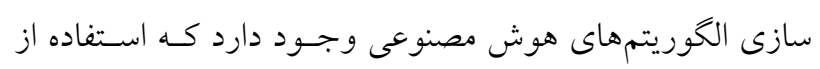

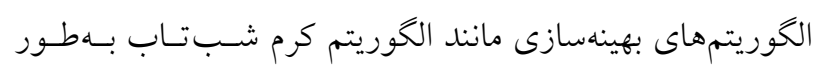
جشمخيرى دقت و انعطاف روش ها محاسـبات نـرم را افـزايش

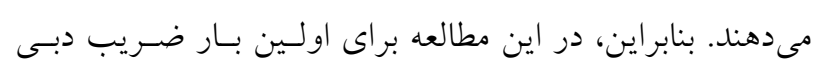

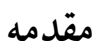

بهطور كلى، سرريزها سازههاى هيدروليكى سادهاى هستـند كـهـ

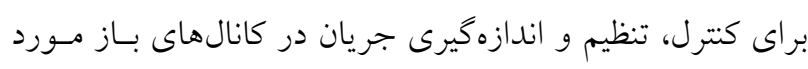

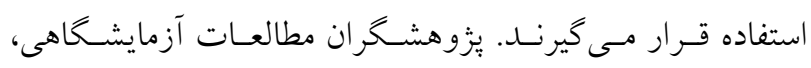
تحليلى و تئوريك بسيارى را روى رفتار هيدروليكى سـرريزهـا

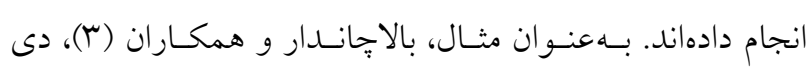

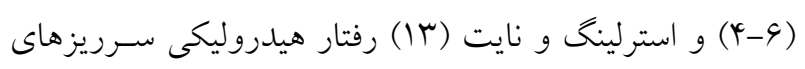

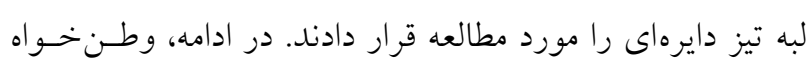
(Y) مقادير دبى و ضريب دبى سرريزهاى دايرهاى را با استفاده

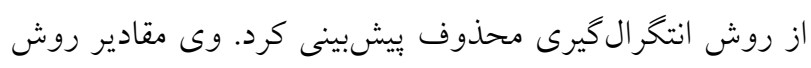

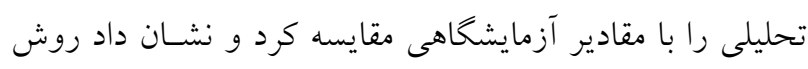

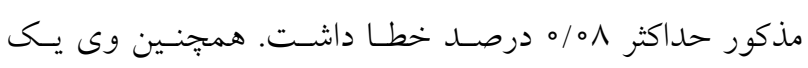

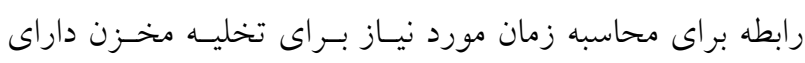

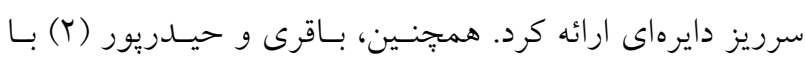

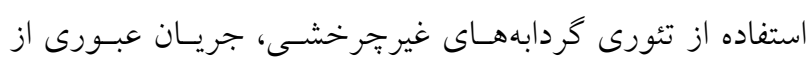

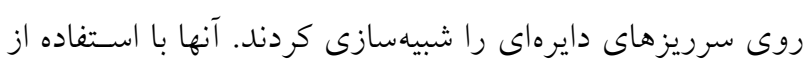

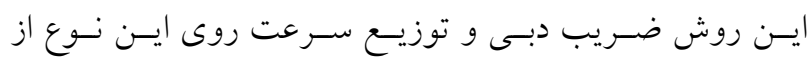

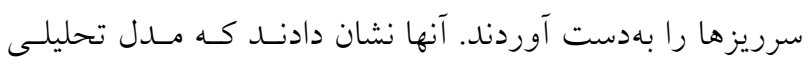

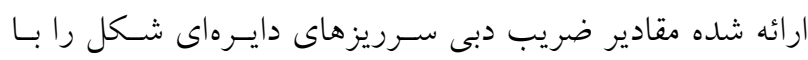

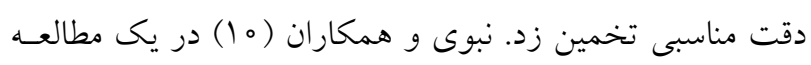

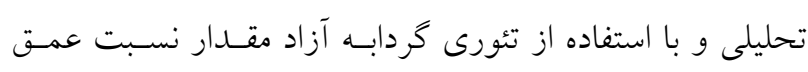

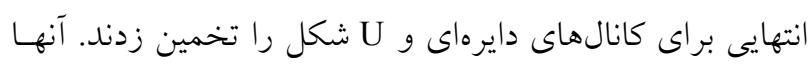

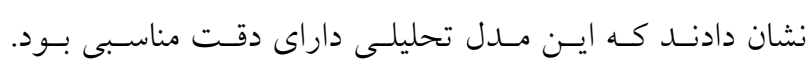

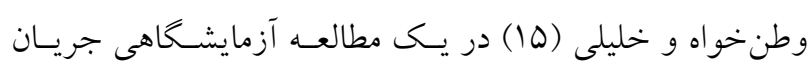
عبورى از روى سرريزهاى دايرهاى را مورد ارزيابى قرار دادنــــا.

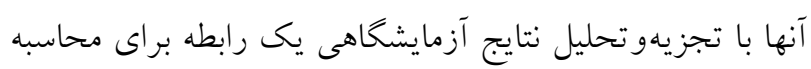

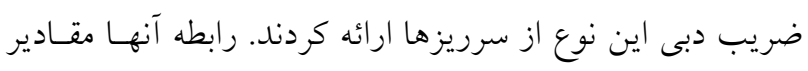
ضريب دبى سرريزهاى دايرهاى را برحسب نسـبت هــــ جريـان روى سرريز به ارتفاع تاج سرريز محاسبه كرد.

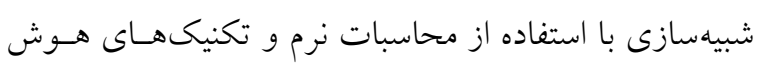

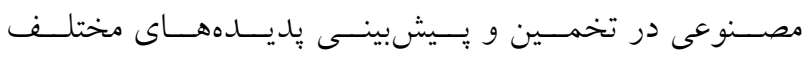

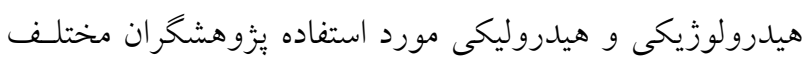




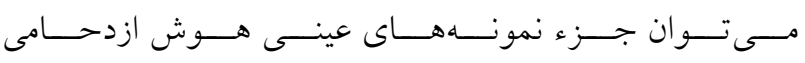
تلقى كرد كه در آن همكارى و احتمـالاً (Swarm intelligence)

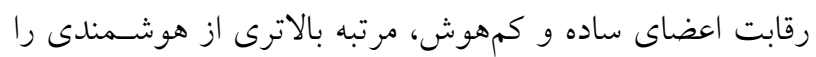

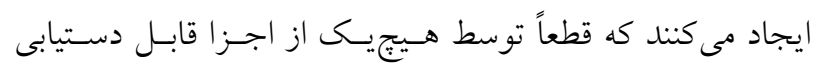
نيست. الكوريتم كرم شبتاب بر بايه قوانين زير ارائسه شـده اسـت

() همه كرمهاى شب تاب دو جنسيتى هستند. بهعبـارت ديخـر،

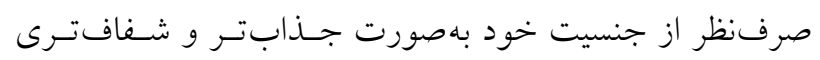
حركت خواهند كرد بهطورى كه يك كرم شبتـاب، كرمهــاى شبتاب ديكر را جذب مى كند.

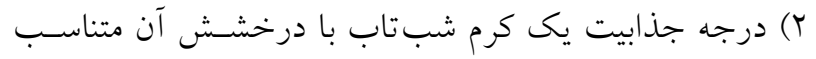
است. همجنين ممكن است درخشندكى با افز ايش فاصـله از

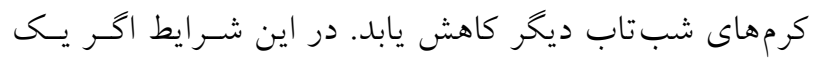

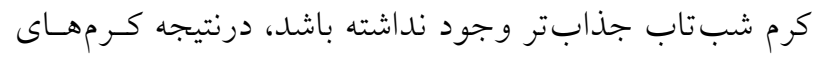
شبتاب ديخر بهصورت تصادفى حركت خواهد كرد.

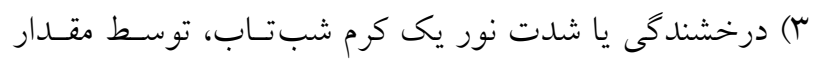
تابع هدف تعيين مى شود.

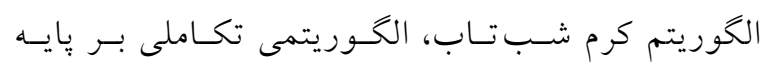
جمعيت است كه از رفتار كرمهاى شبت تاب در جستجوى

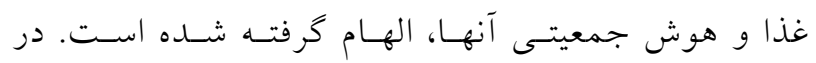
طبيعت كرم هاى شب تاب بهصورت تصادفى حركت مى كنيند

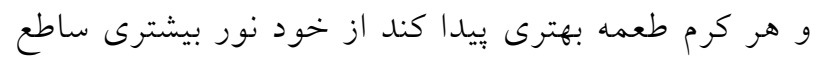

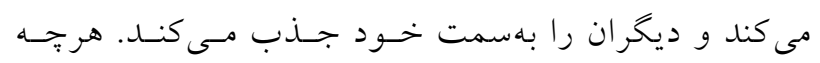

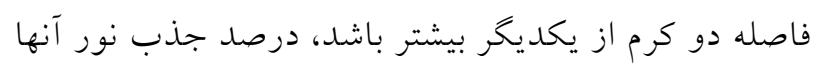

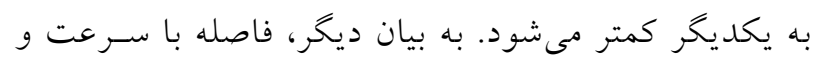

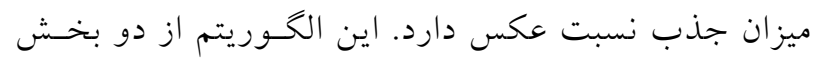

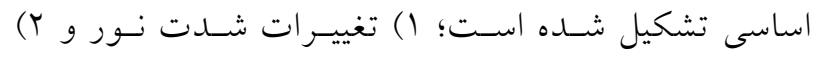

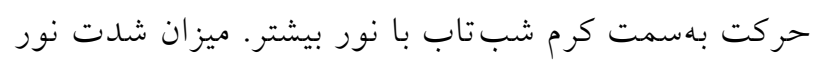

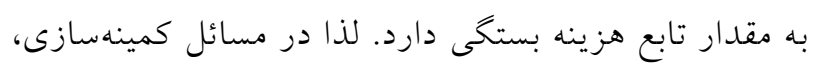

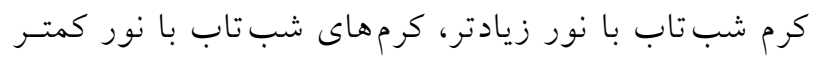
را بهخود جذب مى كند.
سرريزهاى دايرهاى شـكل توسط مــل تركيبى انفـيس - كـرم

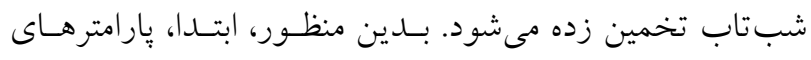

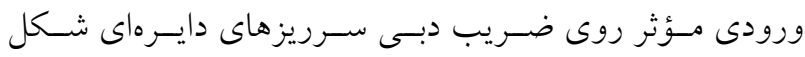

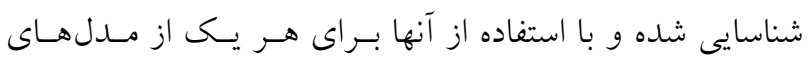

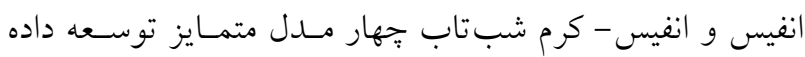

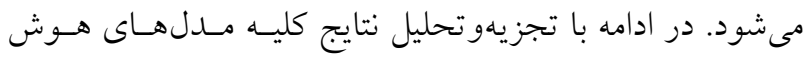

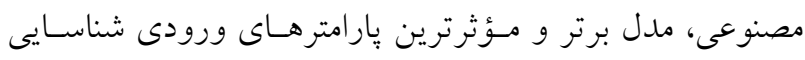

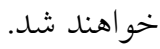

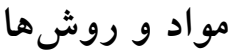

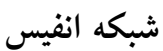

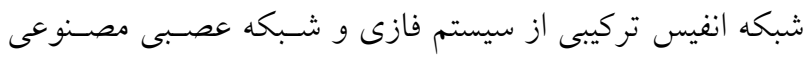

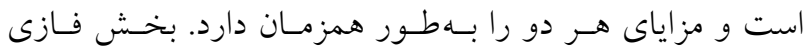
رابطـهاى بـين ورودى و خروجسى برقــرار كـرده و پارامترهــاى

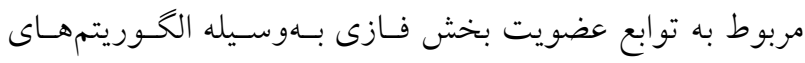

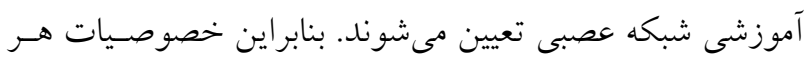
دو مدل فازى و عصسبى در ايسن سيستـم نهفتـه اسـت. سـاختار

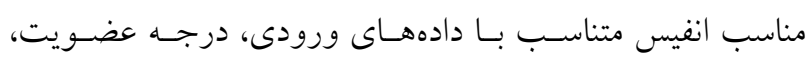

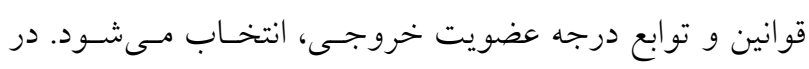

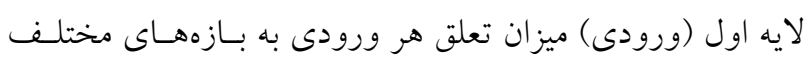

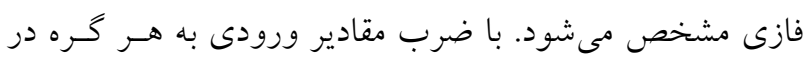

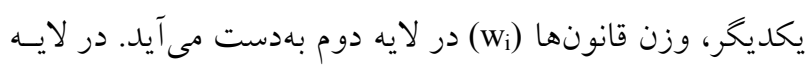

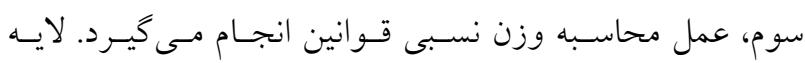

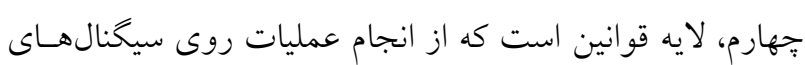

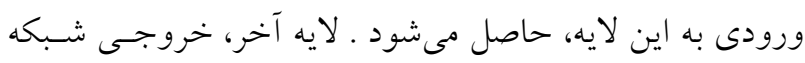

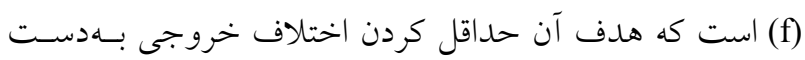

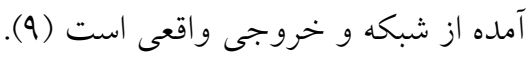

$$
\text { الخوريتم كرم شبتاب }
$$

الخوريتم كرم شـبتــاب (Firefly Algorithm: FA)، اولـينبـار

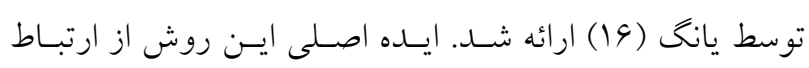

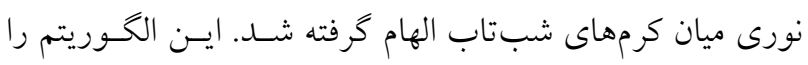




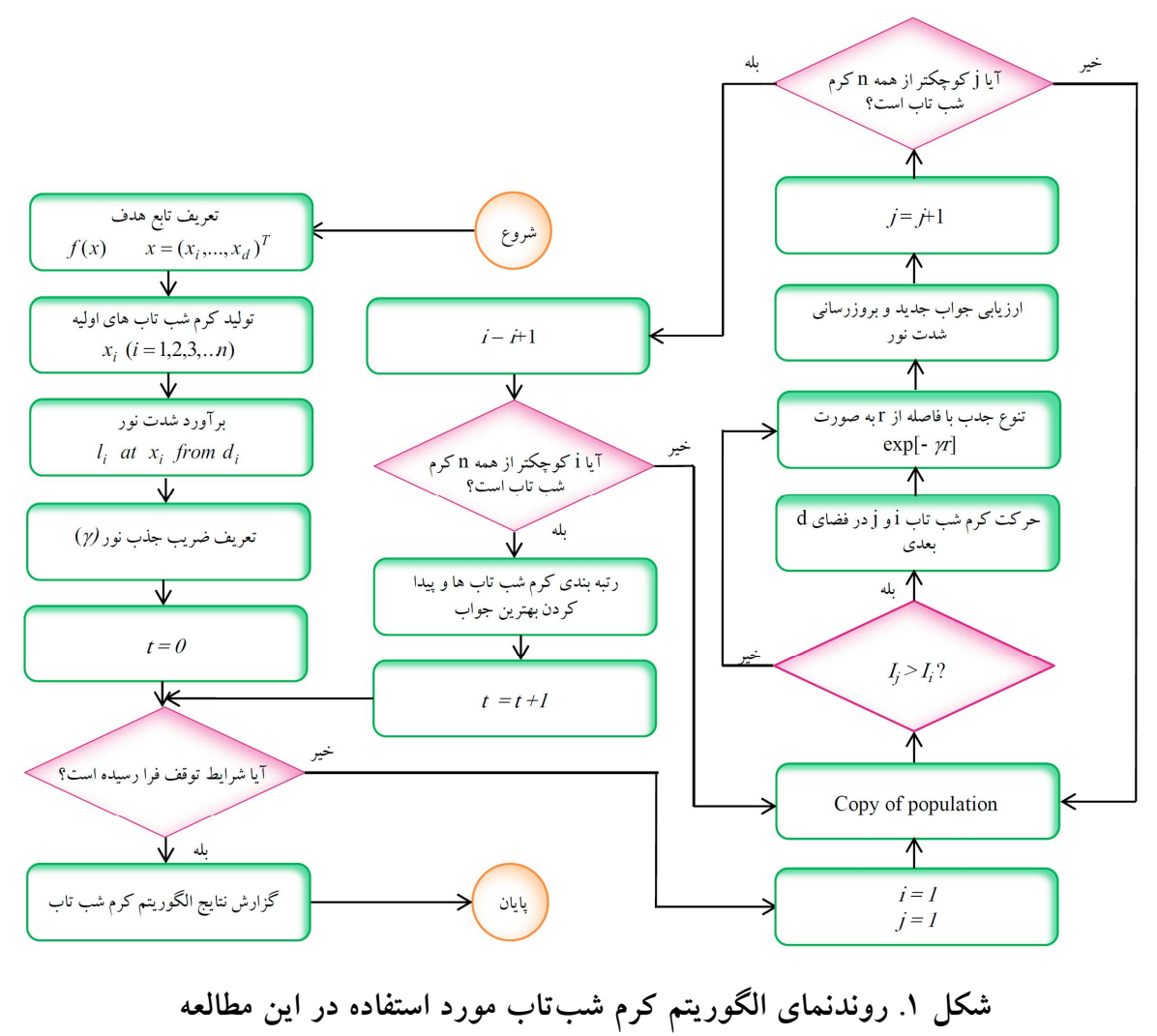

ضريب جذب نرو بيشتر باشد، سرعت جذب افراد جمعيـت بـه سمت يرنورترين فرد، بيشـتر مسىشـود. در شـكل ا رونــنماى الكوريتم كرم شبتاب قابل مشاهده است.

آموزش سيستم استنتاج فازى عصبى تطبيقـى بــا اسـتفاده از الكوريتم كرم شبتاب بهمنظور آموزش انفيس با استفاده از الخــوريتم كـرم شـبـتـاب، ابتدا بايد فضاى حل مثال و يا دامنه متغيرهايى كه نياز بـه بهينـه سازى دارند و تابع شايستخى (fitness function)، تعيسين شـود.

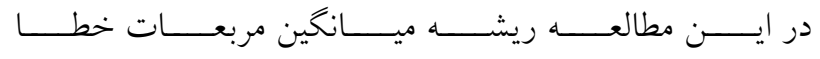
براى ارزيـابى عملكــــ (Root Mean Square Error (RMSE))

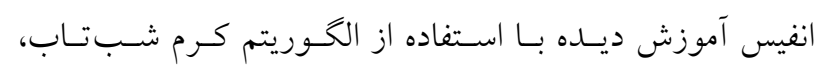
بهعنوان تابع شايستخى مورد اسـتفاده قـرار مسى گيـرد. هـر كـرم شبتاب شامل مجموعهاى از يارامترهاى مقدم (antecedent) و

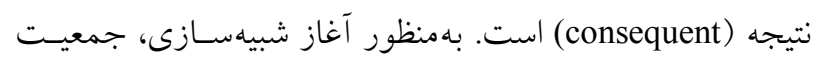
اوليه كرم شبتابها بهطور تصادفى تعيين مىشود. هـر يـك از

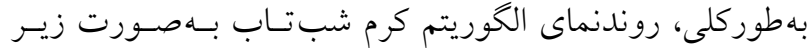
است: 1- تعيين و مقداردهى اوليه كرمهاى شبتاب (جمعيت اوليه)

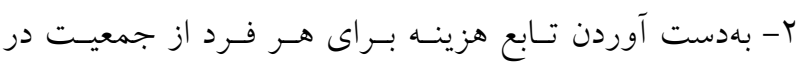
موقعيت خود، r- تخصيص تصادفى شدت نور به هر فرد از جمعيت، ץ- تعيين بهترين (برنورترين) فرد در جمعيت بهواسطه محاسبه توابع هزينه كل افراد جمعيت، ه- حركـت ديخــر افــراد جمعيـت بـهسمت بهتــرين فـرد و بروزرسانى شدت نور با توجه به آن، 9- بررسى شرايط توقف. اخر شرايط توقف مهيـا بـود، حركـت بهسمت مرحله بعـد، در غيـر ايسنصـورت، حركت بـهسمت كام

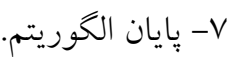
عملكرد الكوريتم كرم شـبتــاب بـهــور كامـل بـهـ تعـداد جمعيت اوليه، تابع جذب و ضريب جذب وابسته است. هر جِه 
ضريب دبى سرريزهاى لبه تيز

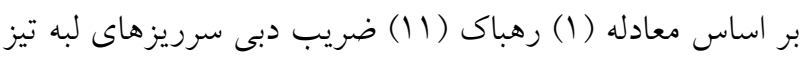
را بهعنوان تابعى از نسبت هد جريان روى سرريز به ارتفاع تاج سرريز (h/P) درنظر كرفت: $\mathrm{C}_{\mathrm{d}}=0.611+0.08\left(\frac{\mathrm{h}}{\mathrm{p}}\right)$

هم:جنين وطن خواه و خليلى (10) ضريب دبسى سـرريزهاى لبـه

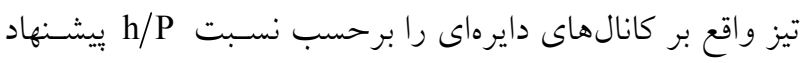

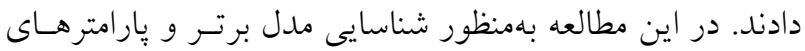

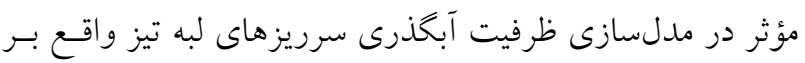

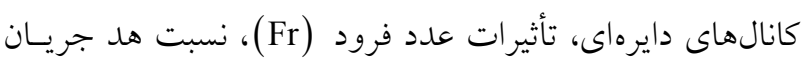
روى سرريز به ارتفاع تاج سرريز (h/P) و نسـبت قطر كانـال

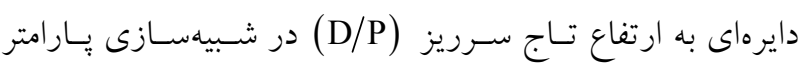
ضريب دبى (C) درنظر كرفته مىشود:

$\mathrm{C}_{\mathrm{d}}=\mathrm{f}\left(\mathrm{Fr}, \frac{\mathrm{h}}{\mathrm{P}}, \frac{\mathrm{D}}{\mathrm{p}}\right)$

براى مدلسازى ضريب دبى سرريزهاى لبه تيز واقـع بـر كانـال

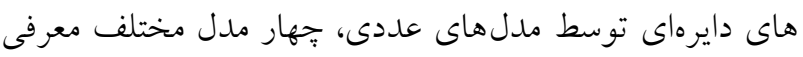

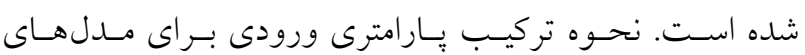

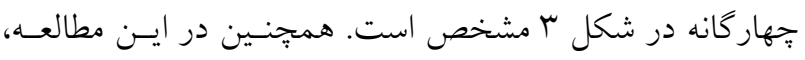

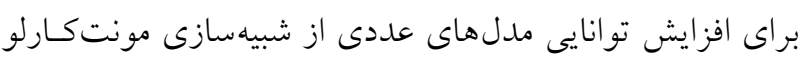

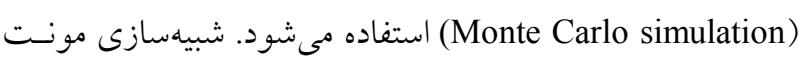

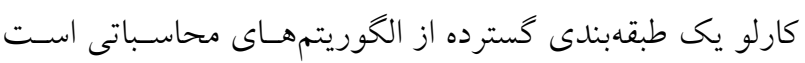
كه از نمونه گيرى تصادفى براى محاسـبه نتـايج عـددى اسـتفاده

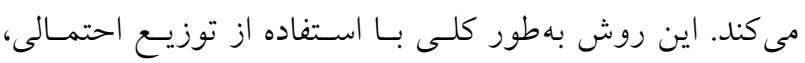

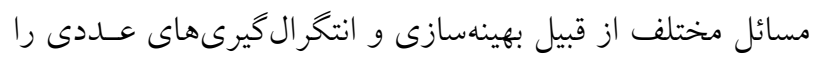

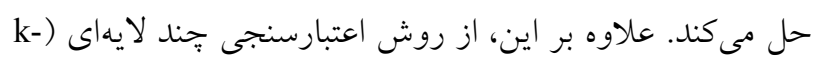

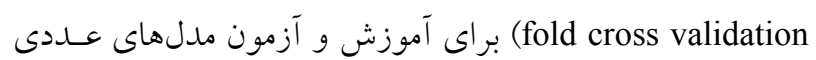

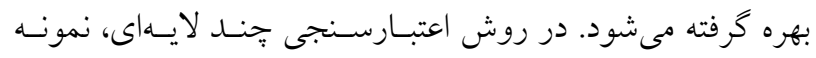
اصلى بهطور تصادفى به k نمونه فرعى به انــازه مســاوى تقسيميم

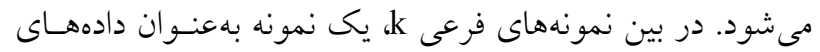

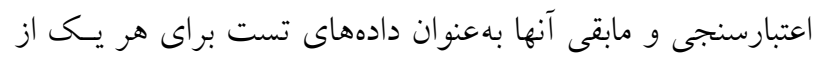

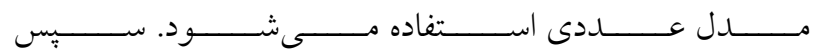

جدول ا. محدوده مقادير آزمايشخاهى وطنخواه و خليلى (10)

\begin{tabular}{|c|c|}
\hline محدوده & 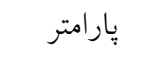 \\
\hline $0.000734-0.038357$ & $\mathrm{Q}\left(\mathrm{m}^{3} / \mathrm{s}\right)$ \\
\hline 0.191 and 0.301 & $\mathrm{D}(\mathrm{m})$ \\
\hline $0.06-0.22$ & $\mathrm{P}(\mathrm{m})$ \\
\hline $0.0139-0.1373$ & $\mathrm{~h}(\mathrm{~m})$ \\
\hline $0.0892-0.2842$ & $\mathrm{y}(\mathrm{m})$ \\
\hline
\end{tabular}

كرمهاى شبتــاب مسى توانـــ بـا مجموعـهـ بارامترهـاى سيسـتم

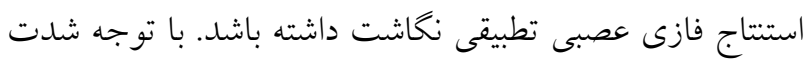
نور مربوط به هر يك از كرمهاى شبتاب، جذابيت مربـوط بـهـ

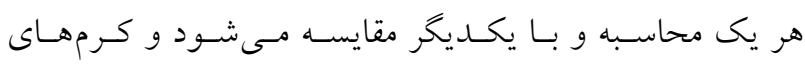
شبتاب با روشنايى كمتر، بهسمت كرمهــاى شـبـتـاب داراى

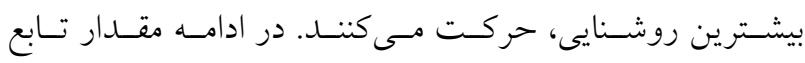
شايستكى محاسبه مى شود. اين روند تا رسيدن به مقــدار تكـرار

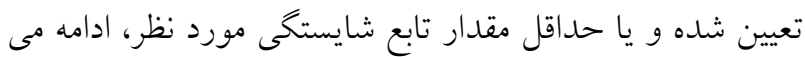

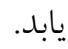

مدل آزمايشخاهى

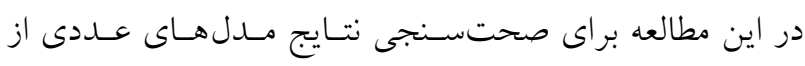

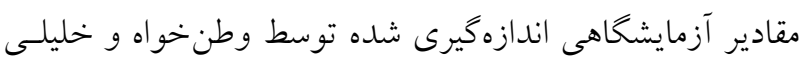

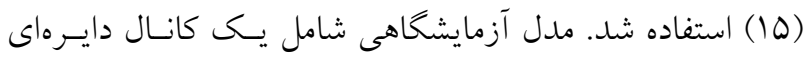

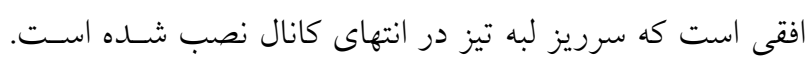

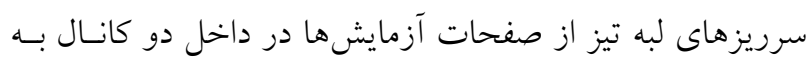

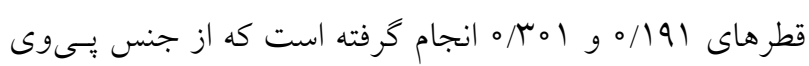

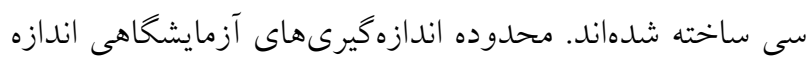

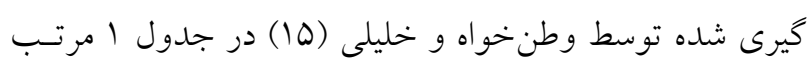

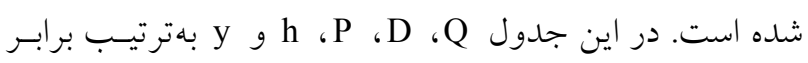
دبى داخل كانال دايرهاى، قطر كانال دايرهاى، ارتفاع تاج سرريز،

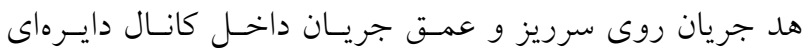

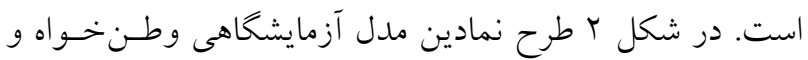
خليلى (Q ا) نشان داده شده است. 


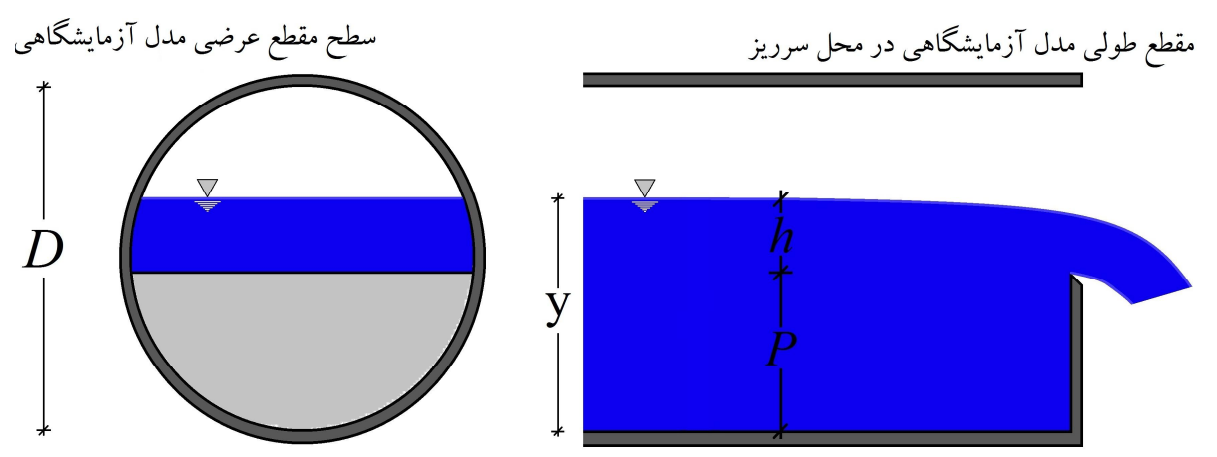

شكل r. طرح نمادين مدل آزمايشگاهى وطنخواه و خليلى (10)

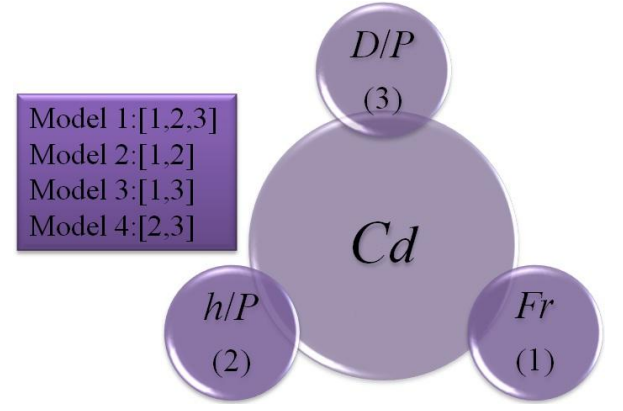

شكل س. نحوه تركيب يارامترهاى مختلف براى بيشبينى ضريب دبى با استفاده از مدل عددى

MARE $=\frac{1}{n} \sum_{i=1}^{n}\left(\frac{\left(C_{d}\right)_{(\text {Predicted })_{i}}-\left(C_{d}\right)_{(\text {Observed })}}{\left(C_{d}\right)_{(\text {Observed })_{i}}}\right) \times 100(\widetilde{r})$

$\operatorname{RMSE}=\sqrt{\frac{1}{\mathrm{n}} \sum_{\mathrm{i}=1}^{\mathrm{n}}\left(\left(\mathrm{C}_{\mathrm{d}}\right)_{(\text {Predicted })_{\mathrm{i}}}-\left(\mathrm{C}_{\mathrm{d}}\right)_{(\text {Observed })_{\mathrm{i}}}\right)^{2}}$

$\mathrm{SI}=\frac{\mathrm{RMSE}}{\overline{\left(\mathrm{C}_{\mathrm{d}}\right)_{(\text {Observed })}}}$

BIAS $=\frac{1}{n} \sum_{i=1}^{n}\left(\left(C_{d}\right)_{(\text {Predicted })_{i}}-\left(C_{d}\right)_{(\text {Observed })_{i}}\right)$

$\mathrm{R}=\frac{\sum_{\mathrm{i}=1}^{\mathrm{n}}\left(\begin{array}{l}\left(\mathrm{C}_{\mathrm{d}}\right)_{(\text {Observed }) \mathrm{i}}-\left(\overline{\mathrm{C}_{\mathrm{d}}}\right)_{(\text {Observed })} \\ \left.\left(\mathrm{C}_{\mathrm{d}}\right)_{(\text {Predicted }) \mathrm{i}}-\left(\overline{\mathrm{C}_{\mathrm{d}}}\right)_{(\text {Observed })}\right)\end{array}\right.}{\sqrt{\left.\sum_{\mathrm{i}=1}^{\mathrm{n}}\left(\mathrm{C}_{\mathrm{d}}\right)_{(\text {Observed }) \mathrm{i}}-\left(\overline{\mathrm{C}_{\mathrm{d}}}\right)_{(\text {Observed })}\right)^{2}}}$

در اينجـــ (Cbserved)i
روند اعتبارسنجى خند لايه، k بار تكرار مىشـود (برابـر تعـداد

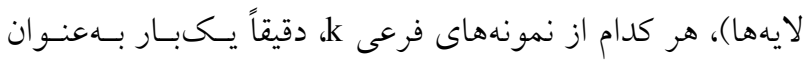

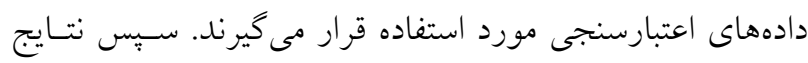

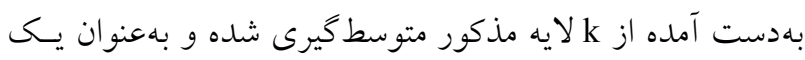
تخمين ارائه مىشود. مزيت ايسن روش، تكـرار تصـادفى نمونسه

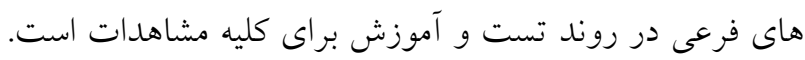

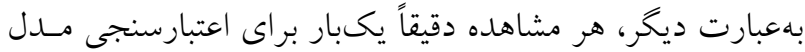
عددى مورد نظر مورد استفاده قـرار مسى گيـــد. در ايـن مطالعـهـ مقدار k برابر ينج درنظر كرفته شده است. بحث و نتايج

(V) بهنظور بررسى دقت نتايج شبيهسازى ضريب دبى روزنه جانبى توسط مدلهاى عددى از شاخص هاى آمـارى درصـد ميـانخين

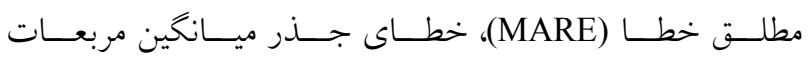

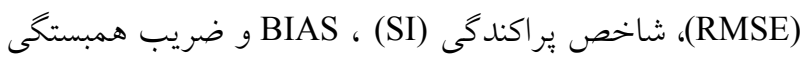
(R) استفاده مىشود: (R) 


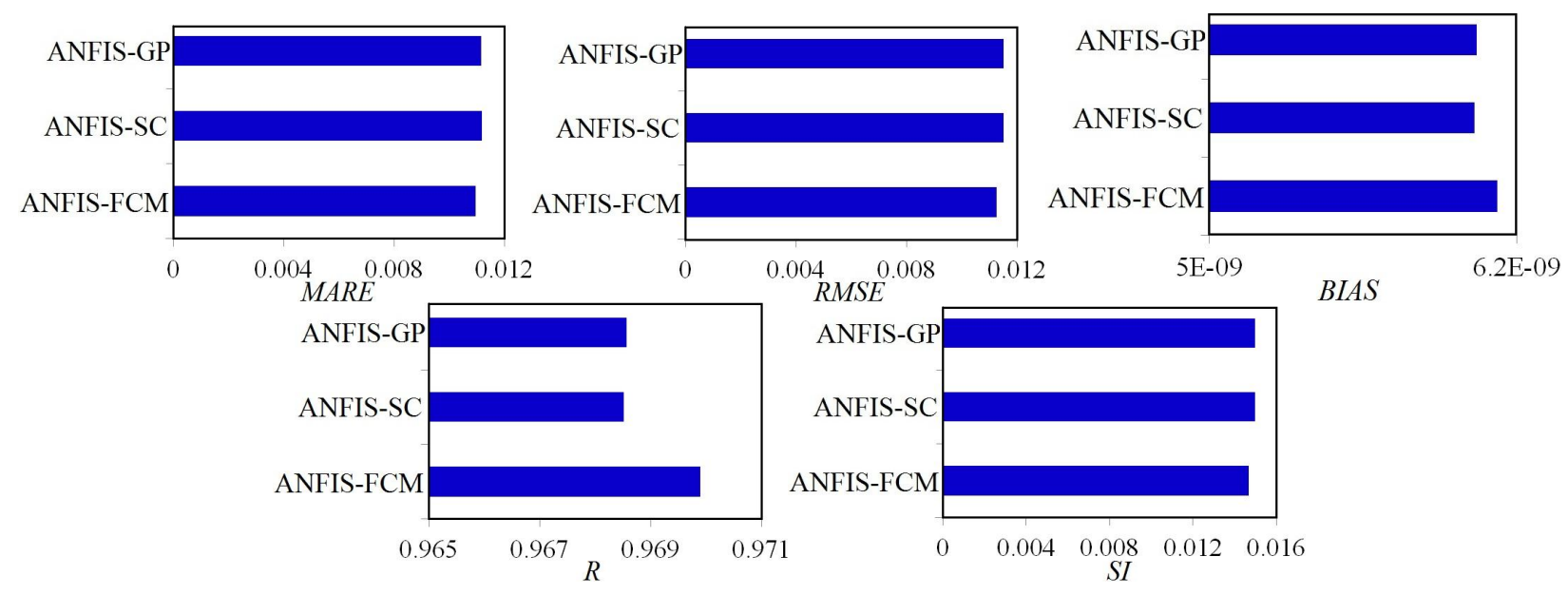

شكل گ. نتايج شاخصهاى آمارى مختلف براى نسل هاى مختلف سيستم استتاج فازى
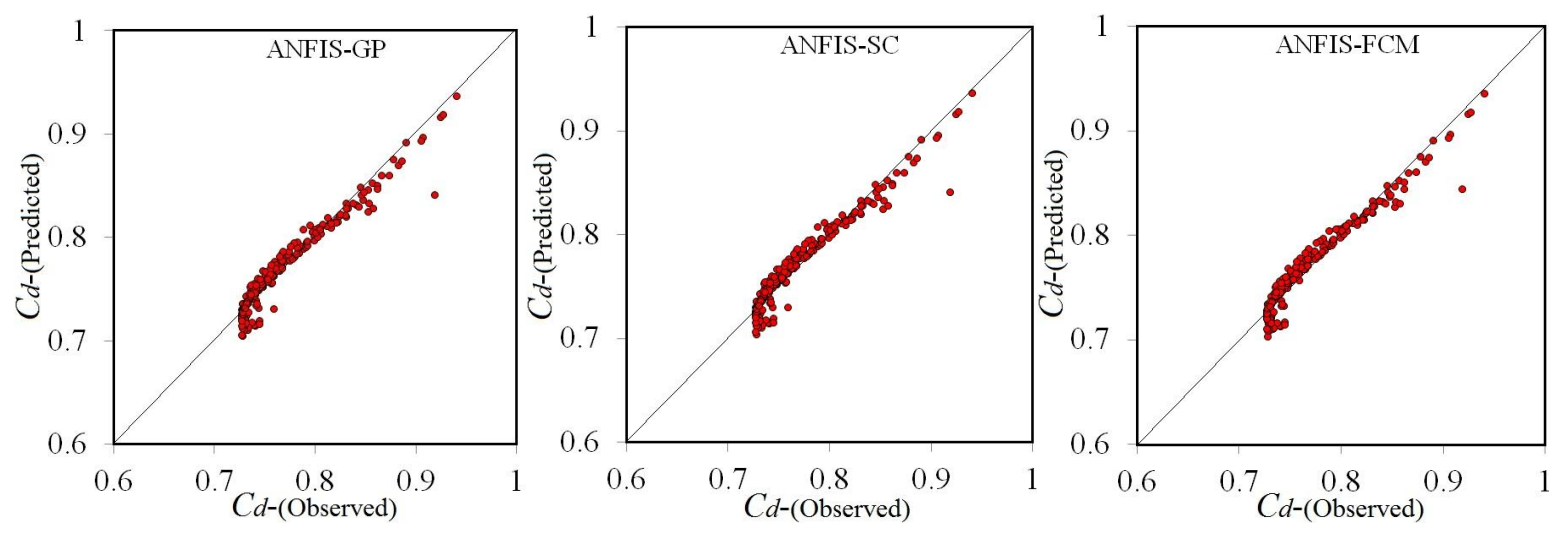

شكل ه. نمودارهاى يراكندگى براى نسل هاى مختلف سيستم استتاج فازى

ANFIS با مقادير مشاهداتى در شـكل ه قابـل مشـاهده اسـت.

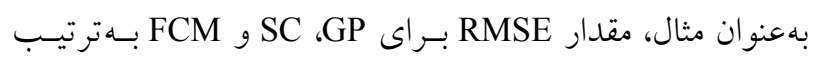

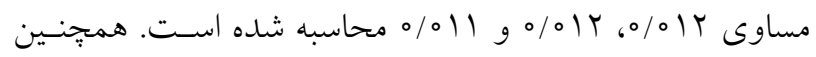

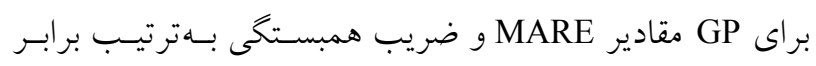

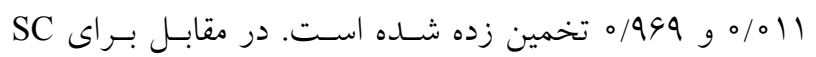

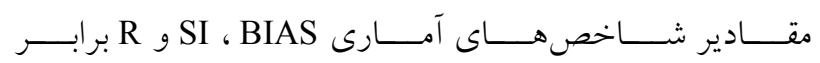

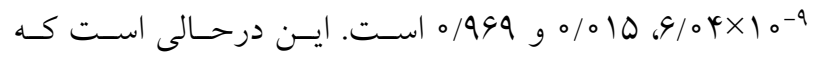

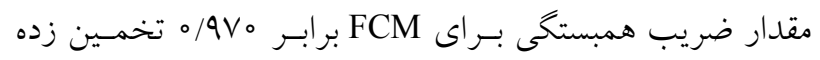

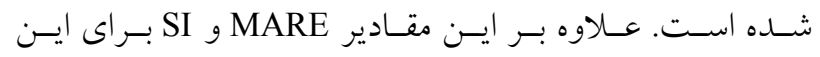
FIS generation شده است. بنابر اين همانطور كه مشـاهده مسىشـود، SC داراى كمترين دقت در مدلسازى ضـريب دبسى سـرريزهاى دايسرهاى
ضريب دبى ييشبينسى شـده بـهوسـيله مـدل $\left(C_{d}\right)_{(\text {Predicted)i }}$ عددى، بر بر تعداد اندازهيرىهاى آزمايشگاهى است. بر رسى نسل هاى مختلف سيستم استنتاج فازى

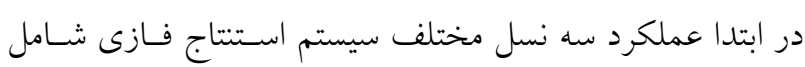
و Subtractive Clustering (SC) ،Grid Partitioning (GP) Fuzzy C-Means Clustering (FCM)

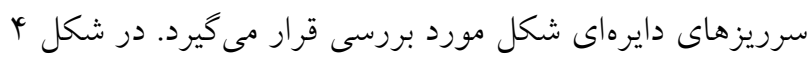

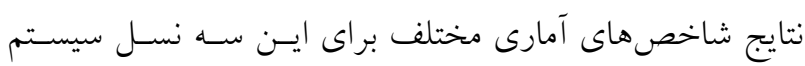

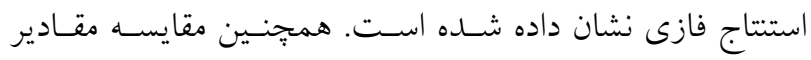

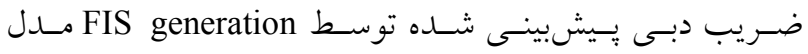




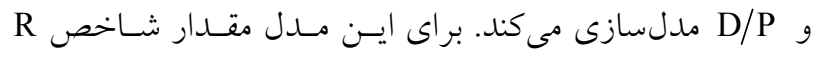

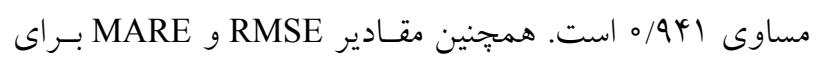

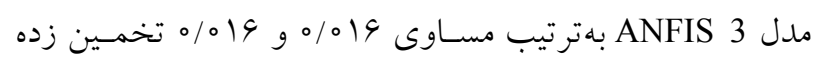

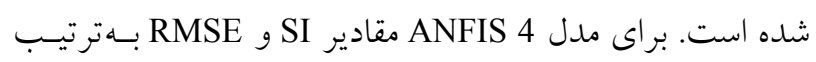

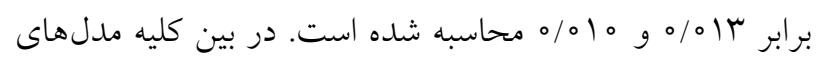

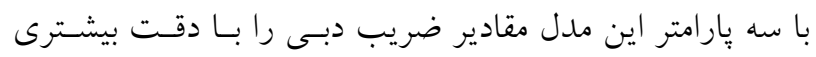

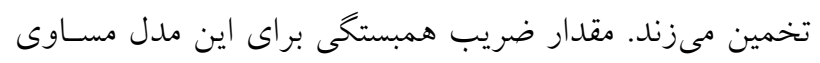

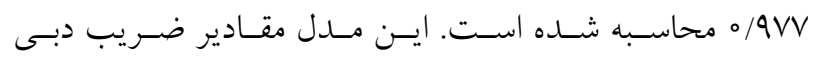

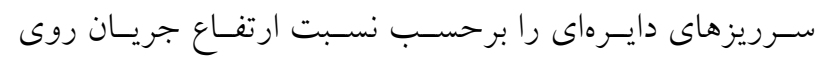

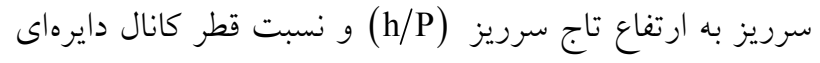
به ارتفاع تاج سرريز (D/P) مدلسازى مى كند. بهعبارت ديخـر

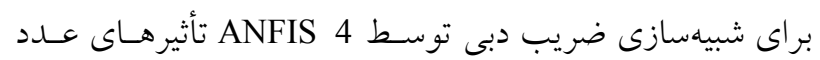
فرود حذف شده است. در ادامه بهمنظور بررسى بيشتر دقت مدلهاى عددى ضريب اختلاف (DR) (Discrepancy Ratio مدلهـاى مـذكور مـورد

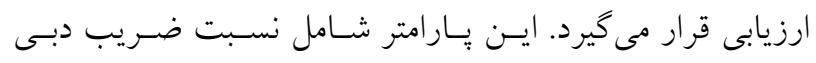
شبيهسازى شده به ضريب دبى مشاهداتى است:

$\mathrm{DR}=\mathrm{R}_{\text {Predicted }} / \mathrm{R}_{\text {Observed }}$

همجنين ضريب اختلاف حداكثر، حداقل و متوسط بهترتيب بـا

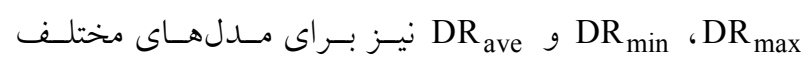

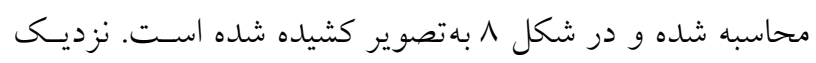

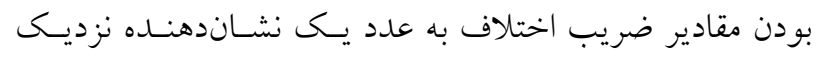

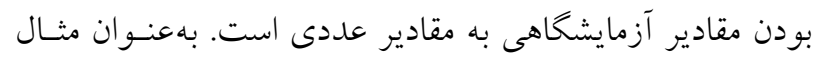

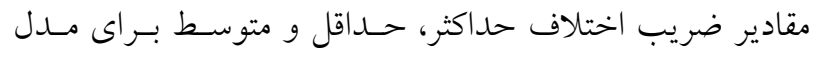
ANFIS 1

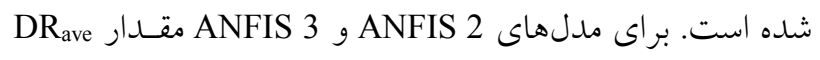

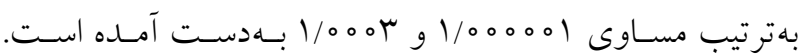
علاوه بر اين مقدار ضريب اختلاف حداكثر براى مــدل ANFIS 4 مساوى 19/19 محاسبه شده است.

مدلهاى ANFIS-FA در ادامـه نتـايج مــلـهـاى ANFIS-FA بررسى مسىشـوند. در
اسـت. در مقابـل FCM داراى بيشـترين دقـت در مـــلســـــ

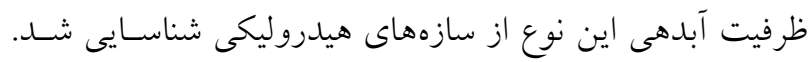

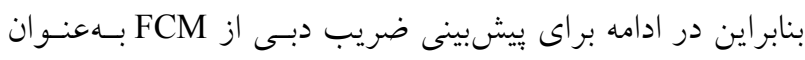
FIS generation

مدلهاى ANFIS

در اين مطالعه جِهار مدل مختلف ANFIS براى تخمين ضـريب

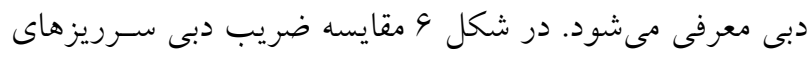

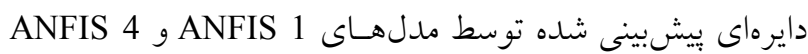

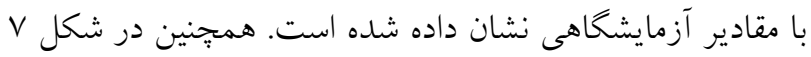

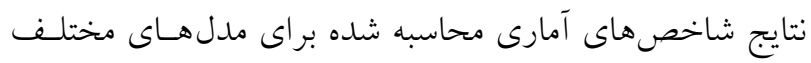
ANFIS

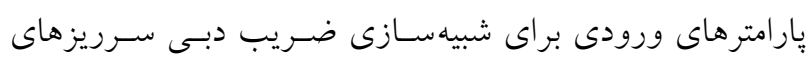

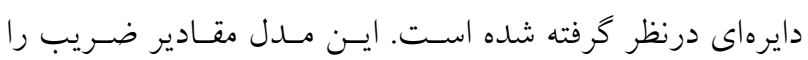

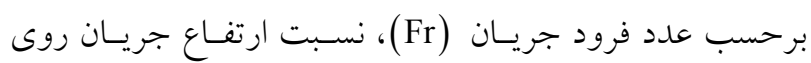

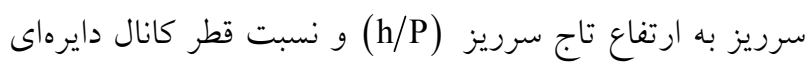

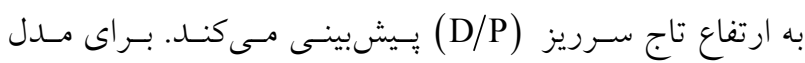
ANFIS 1

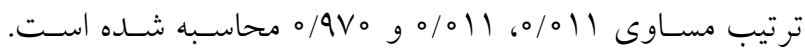

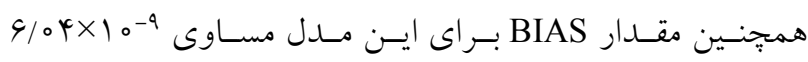

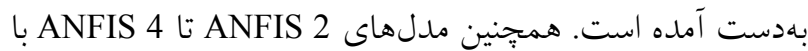
تركيبى از دو بارامتر ورودى مقادير ضريب دبسى را شـبيهسـازى مى كنند. بهعنوان مثال مدل ANFIS 2 تابعى از عدد فرود جريان (Fr) )، نسبت ارتفاع جريان روى سرريز به ارتفـاع تـاج سـرريز شبيهسازى مى كند. براى اين مدل تأثير نسبت قطر كانال

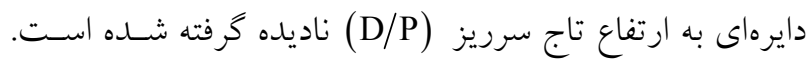
براى اين مدل مقادير SI و ضريب همبستخى بهترتيـب مسـاوى

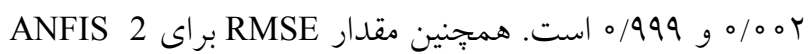

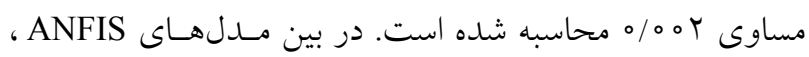

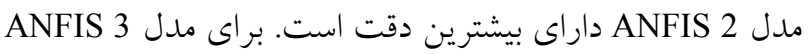

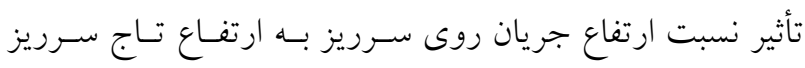

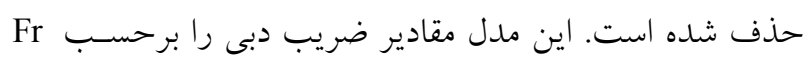


شبيه سازى ضر يب دبى سرريزهاى لبه تيز دايرهاى توسط مدل تر كيبى انفيس-كرم شبتاب

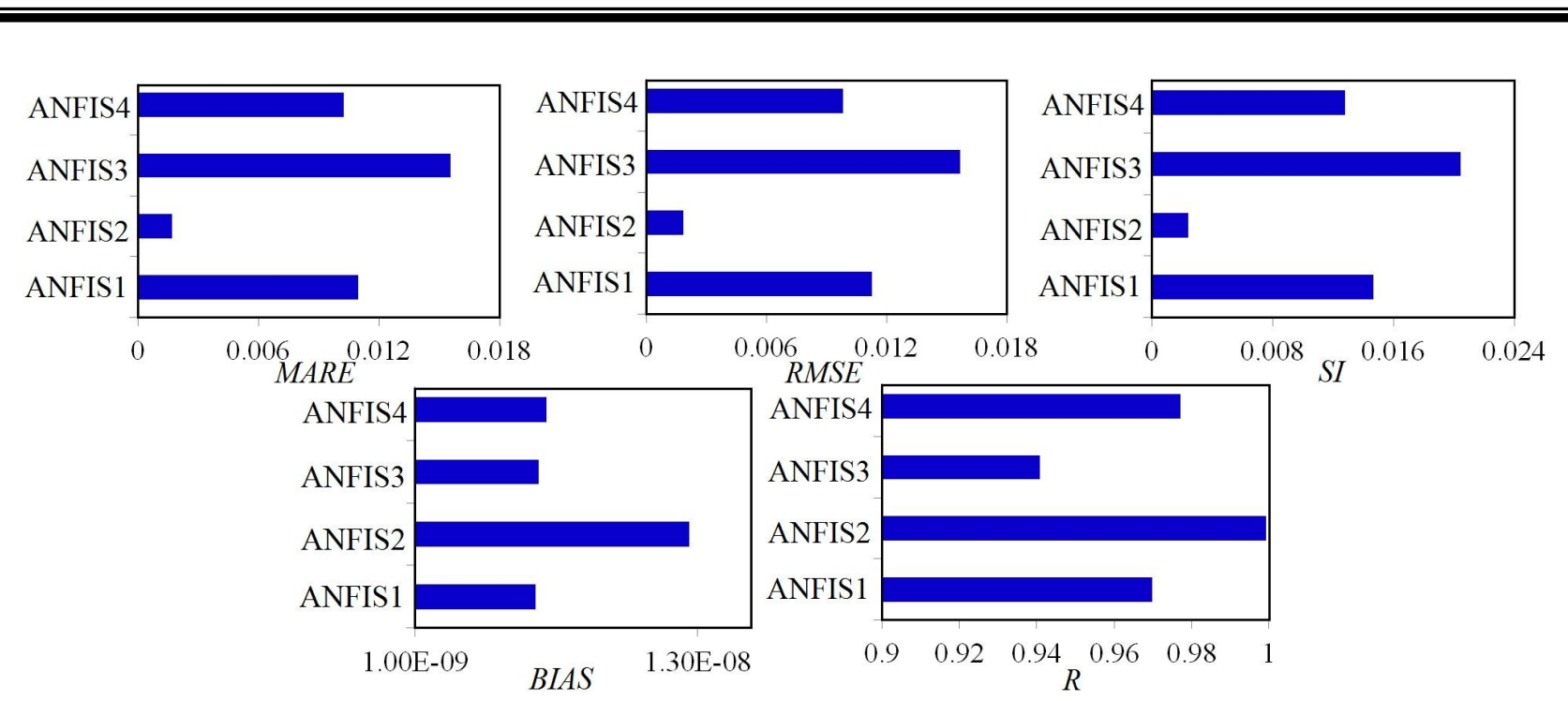

شكل و. نتايج شاخصهاى آمارى براى مدلهاى ANFIS
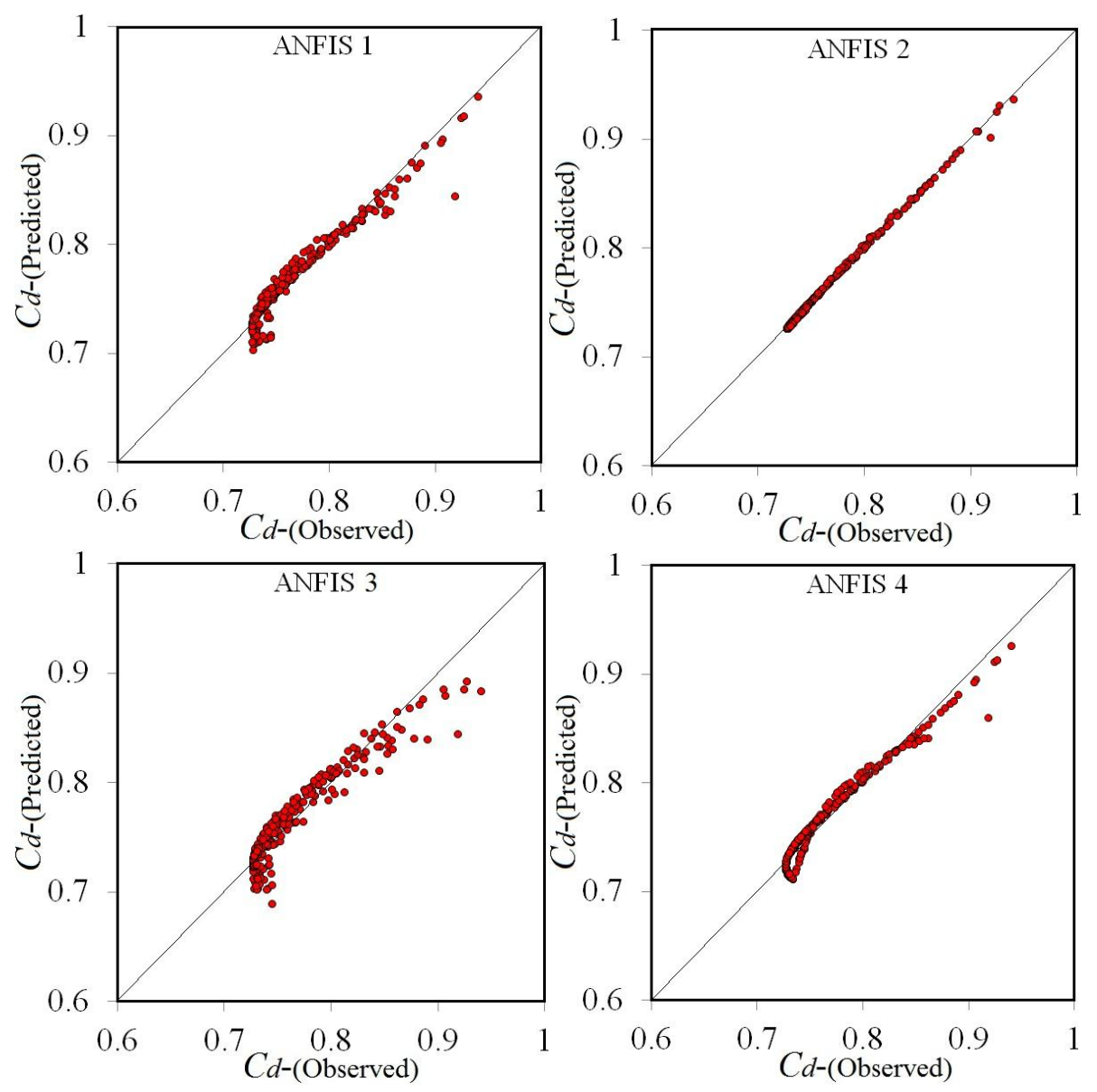

شكل V. نمودارهاى بر اكندگى براى مدلهاى مختلف 

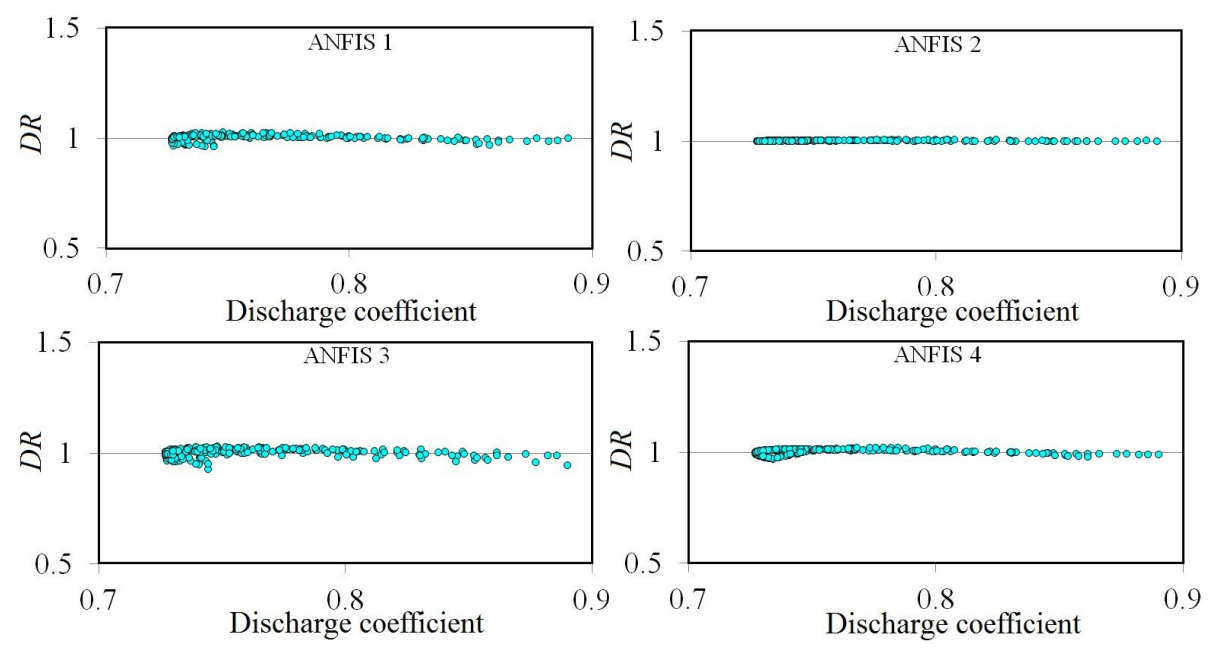

ANFIS Aكل ^ . تغييرات نسبت اختلاف در مقابل ضريب دبى مشاهداتى براى مدلهاى مختلف
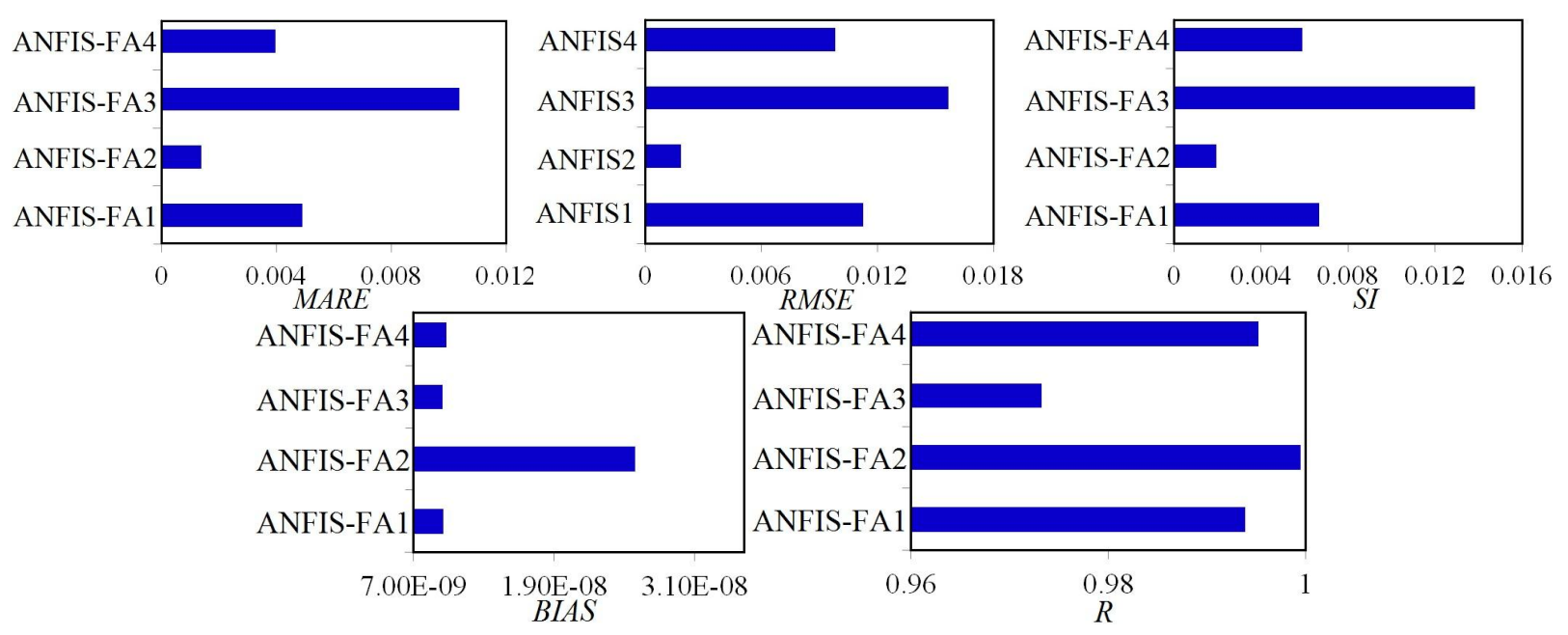

ANFIS-FA شكل q. نتايج شاخصهاى آمارى براى مدلهاى مختلف

تركيبى 2 ANFIS-FA داراى بيشـترين همبسـتكى بـا مقـادير

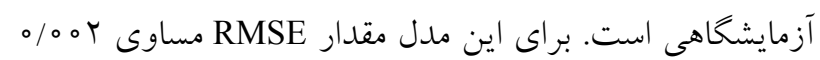

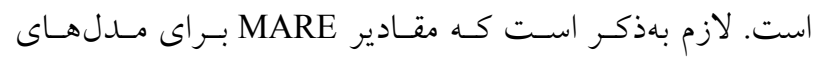
ANFIS-FA و ANFIS-FA 3 Pاى ANFIS-FA 4

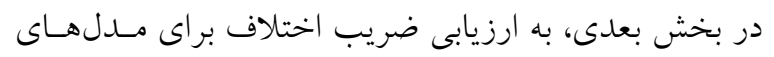

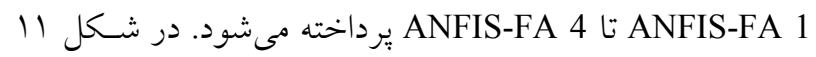
توزيع مقدار ضريب اختلاف براى اين مدل ها نشـان داده شـده

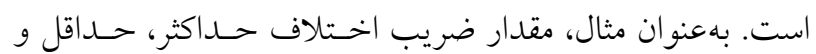

شكل 9 نتايج شاخص هاى آمارى مختلف بـراى ايسن مـدلهــا

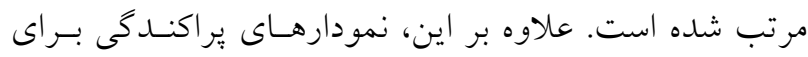

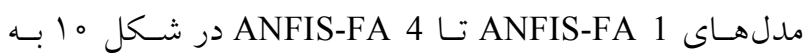
تصوير كشيده شده است. بهعنوان مثال مقدار شاخص R براى

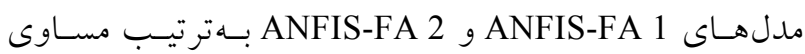

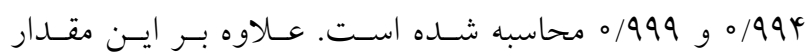

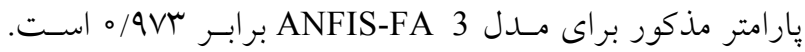

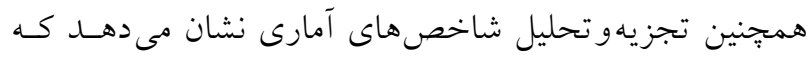

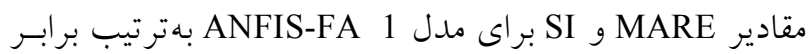

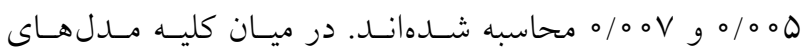



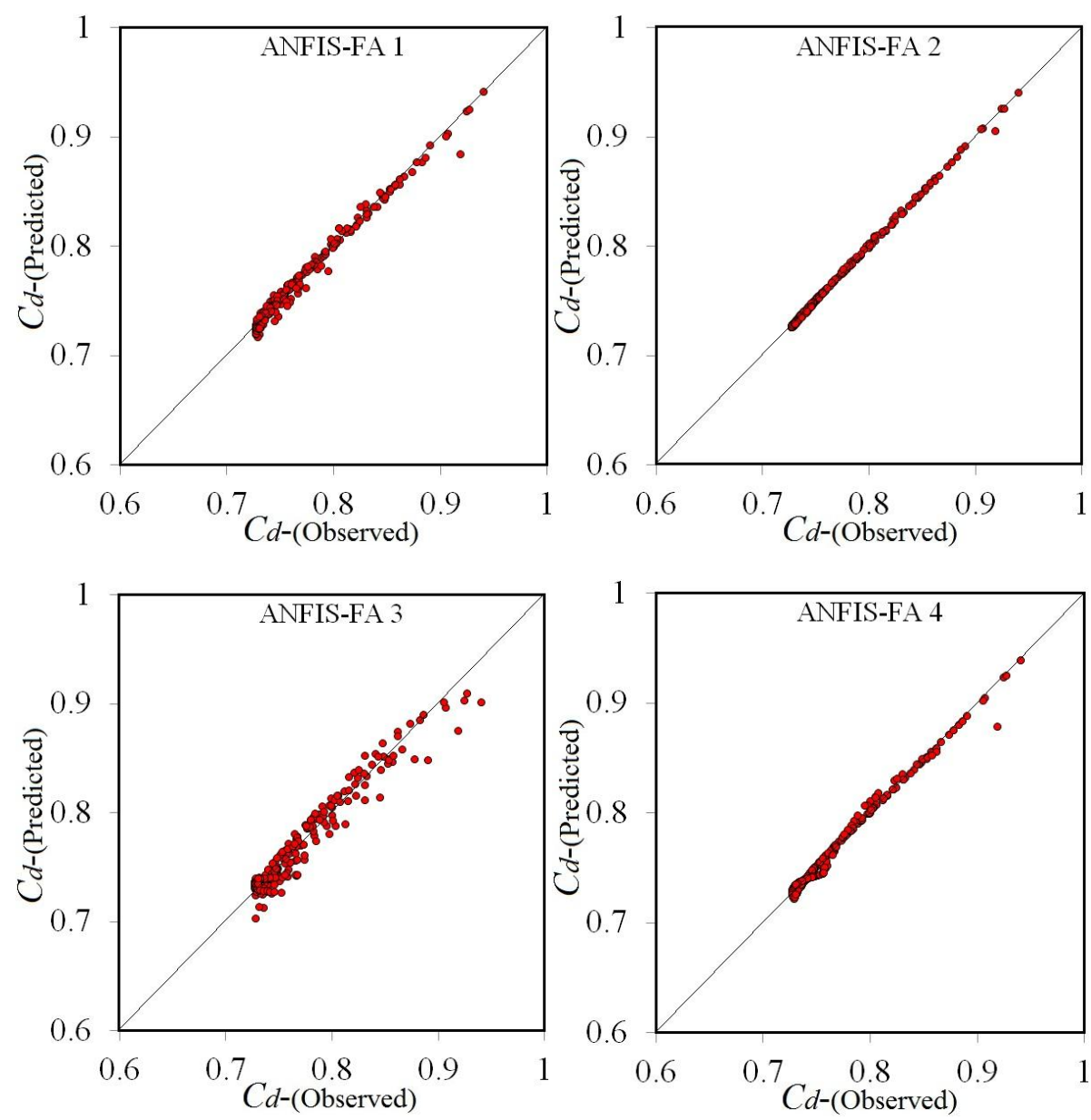

شكل • ا. نمودارهاى براكندگى براى مدلهاى ANFIS-FA
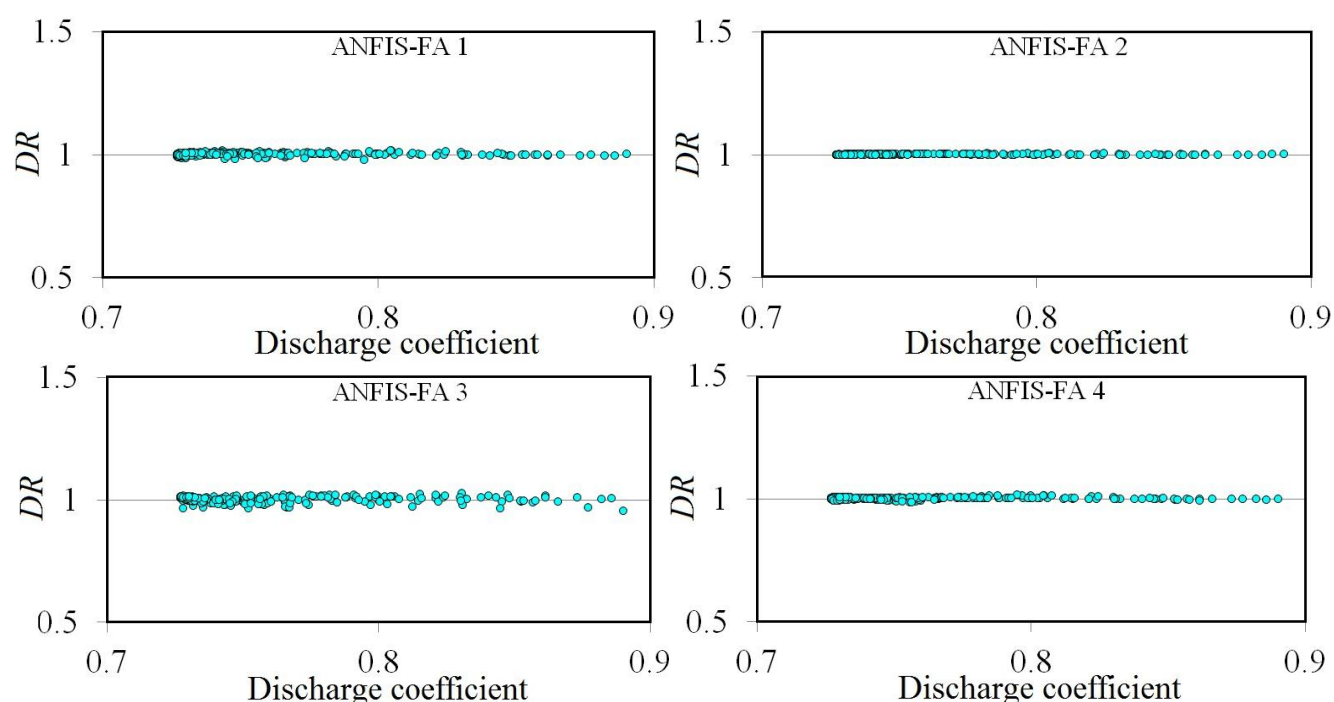

ANFIS-FA شكل ال. تغييرات نسبت اختلاف در مقابل ضريب دبى مشاهداتى براى مدلهاى مختلف 


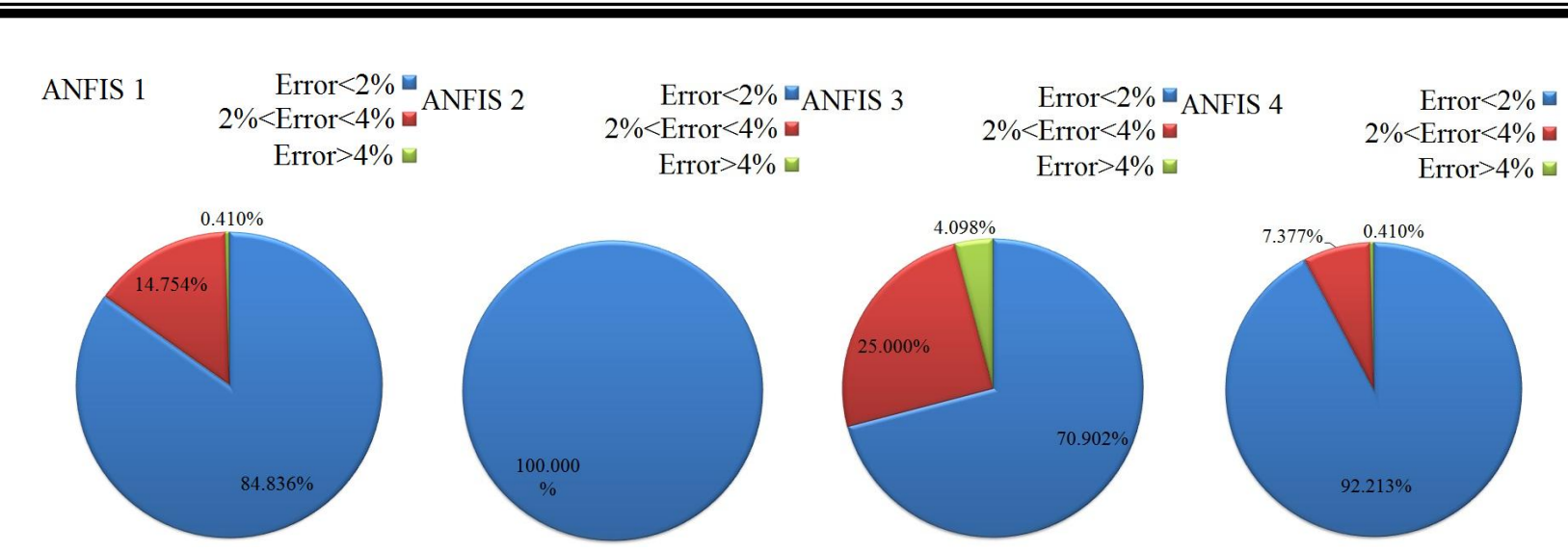

شكل r I نمودارهاى توزيع خطا براى مدلهاى ANFIS

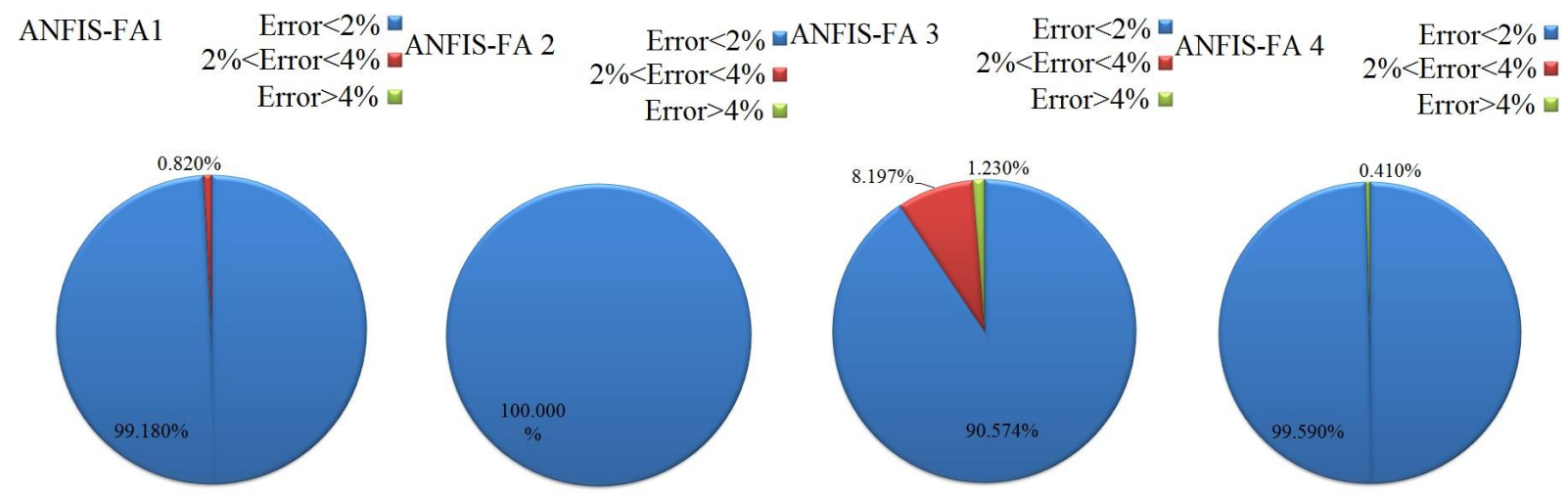

شكل rا. نمودارهاى توزيع خطا براى مدلهاى ANFIS-FA

درصد هستند. علاوه بـر ايسن، تقريبـاً نسيم درصـد نتـايج مــل ANFIS 1 نتايج توزيع خطا، كل مقادير ضريب دبى شبيهسازى شده توسط ANFIS 2

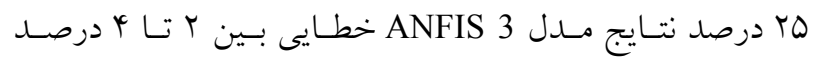
دارند. همجنين حدودا بو درصد نتايج شبيهسازى شـده توسـط خطايى كمتر از ب درصد دارند. ANFIS 4

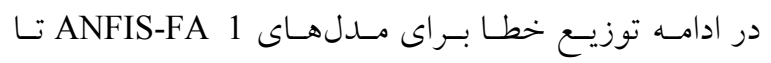
ANFIS-FA 4

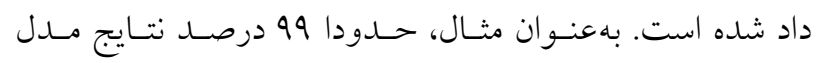
ANFIS-FA 1 مدل يك درصد نتايج داراى خطايى بين r تـا ب درصـد دارنـد.

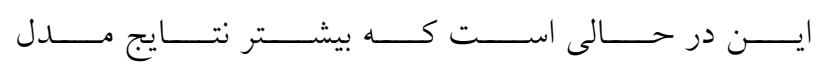
ANFIS-FA 2

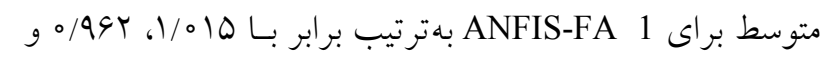

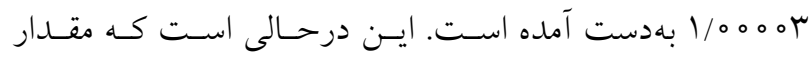
براى مدلهاى ANFIS-FA و 2 و ANFIS-FA 3 بهترتيب

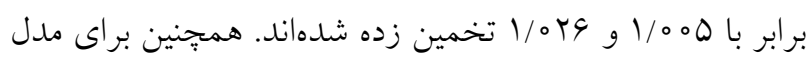

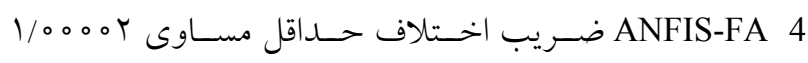
محاسبه شده است.

توزيع خطا در ادامه به بررسى توزيع خطا براى مدلهـاى ANFIS يرداختـه. مىشود. در شكل rا نتايج توزيع خطا براى مــلهـاى ANFIS به تصوير كشيده شده است. بر اساس نتايج شبيهسـازى، حسدوداً

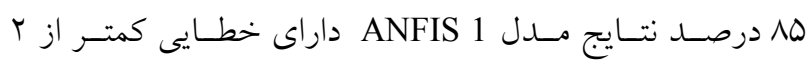

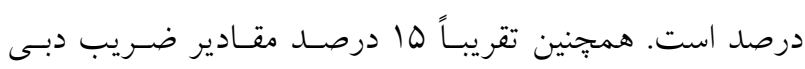

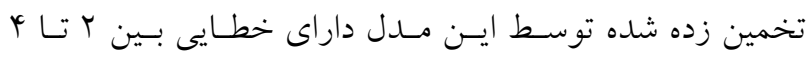




$$
\begin{aligned}
& \text { مدل يك درصد نتايج داراى خطايى بين r تـا ب درصـد دارنـد. }
\end{aligned}
$$

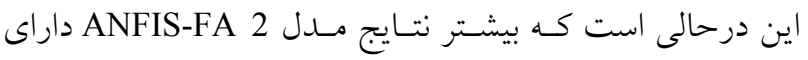

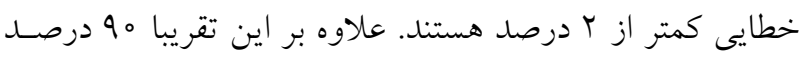

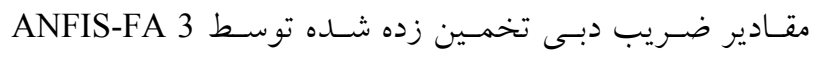

$$
\begin{aligned}
& \text { مقدار خطايى كمتر از Y درصد دارند. همجينين بر اسـاس نتس نسايج }
\end{aligned}
$$

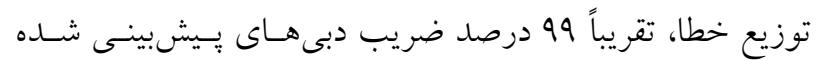

$$
\begin{aligned}
& \text { توسط ANFIS-FA } 4 \text { خطايى كمتر از ب درصد دارند. }
\end{aligned}
$$

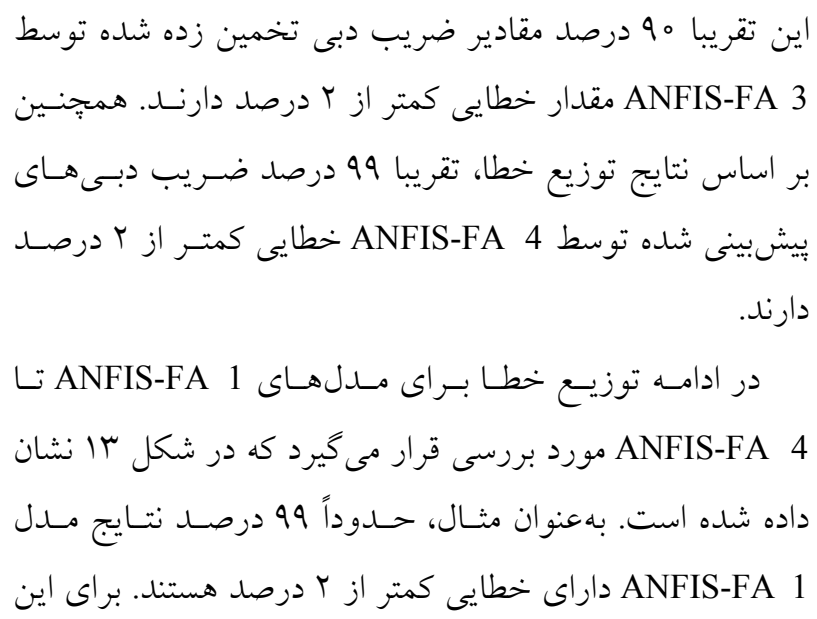

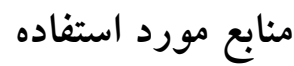

1. Azamathulla, H. M., Z. Ahmad and A. A. B. Ghani. 2013. Computation of discharge through side sluice gate using gene-expression programming. Irrigation and Drainage 62: 115-119.

2. Bagheri, S. and M. Heidarpour. 2010. Overflow characteristics of circular-crested weirs. Journal of Hydraulic Research 48(4): 515-520.

3. Balachandar, R., S. Sorbo and A. S. Ramamurthy. 1991. A note on circular sharp-crested weirs. Canadian Journal of Civil Engineering 18(5): 881-885.

4. Dey, S. 1998. End depth in circular channels. Journal of Hydraulic Engineering 124(8): 856-863.

5. Dey, S. 2001. EDR in circular channels. Journal of Irrigation and Drainage Engineering 127(2): 110-112.

6. Dey, S. 2002. Free overall in circular channels with flat base: a method of open channel flow measurement. Flow Measurement and Instrumentation 13(5): 209-221.

7. Dursun, O. F., N. Kaya and M. Firat. 2012. Estimating discharge coefficient of semi-elliptical side weir using ANFIS. Journal of Hydrology 426-427: 55-62.

8. Ebtehaj, I., H. Bonakdari, F. Khoshbin and H. Azimi. 2015. Pareto genetic design of group method of data handling type neural network for prediction discharge coefficient in rectangular side orifices. Flow Measurement and Instrumentation 41: 67-74.

9. Jang, J. S. R., C. T. Sun and E. Mizutani. 1997. Neuro-Fuzzy and Soft Computing. Prentice Hall. ISBN 0-13-2610663.

10. Nabavi, S. V., M. K. Beirami, M. R. Chamani and M. Sterling. 2011. Free overfalls in flat-based circular and Ushaped channels. Flow Measurement and Instrumentation 22(1): 17-24.

11. Rehbock, T. 1929. Discussion of "precise weir measurements" by Schoder E. W. and K. B. Turner. Trans 93: 11431162.

12. Shabanlou, S. 2018. Improvement of extreme learning machine using self-adaptive evolutionary algorithm for estimating discharge capacity of sharp-crested weirs located on the end of circular channels. Flow Measurement and Instrumentation 59: 63-71.

13. Sterling, M. and D. W. Knight. 2001. The free overfall as a flow measuring device in a circular channel. In Proceedings of the Institution of Civil Engineers-Water and Maritime Engineering (148(4): 235-243). Thomas Telford Ltd.

14. Vatankhah, A. R. 2010. Flow measurement using circular sharp-crested weirs. Flow Measurement and Instrumentation 21(2): 118-122.

15. Vatankhah, A. R. and S. Khalili. 2016. Sharp-crested weir located at the end of a circular channel. In Proceedings of the Institution of Civil Engineers-Water Management (170(6): 287-297). Thomas Telford Ltd.

16. Yang, X. -S. 2010. Nature-inspired metaheuristic algorithms: Luniver Press, Bekhington. 


\title{
Simulation of Discharge Coefficient of Sharp-Crested Circular Weirs Using Hybrid ANFIS-Firefly Model
}

\author{
A. Alizadeh, B. Yaghoubi* and S. Shabanlou ${ }^{1}$
}

(Received: December 18-2018 ; Accepted: September 24-2019)

\begin{abstract}
In this study, the discharge coefficient of sharp-crested weirs located on circular channels was modeled using the ANFIS and ANFIS-Firefly (ANFIS-FA) algorithm. Also, the Monte Carlo simulations (MCs) were used to enhance the compatibilities of the soft computing models. However, the $\mathrm{k}$-fold cross validation method $(\mathrm{k}=5)$ was used to validate the numerical models. According to the input parameters, four models of ANFIS and ANFIS-FA were introduced. Analyzing the numerical results showed that the superior model simulated the discharge coefficient as a function of the Froude number $(F r)$ and the ratio of flow depth over weir crest to the weir crest height $(h / P)$. The values of the mean absolute relative error (MARE), root mean square error (RMSE) and correlation coefficient $(R)$ for the superior model were calculated $0.001,0.002$ and 0.999 , respectively. However, the maximum error value for this study was less than $2 \%$.
\end{abstract}

Keywords: Circular weir, Discharge coefficient, Modeling, ANFIS, ANFIS-FA

1. Department of Water Engineering, Kermanshah Branch, Islamic Azad University, Kermanshah, Iran.

*: Corresponding author, Email: behrouz.yaghoubi.h@gmail.com 